\title{
クレロダンジテルペノイドの合成研究一天然物合成 における立体制御の事例
}

\author{
野老山喬*
}

\section{Synthetic Studies on Clerodane Diterpenoids - A Case of the Stereocontrols in Natural Products Synthesis}

Takashi ToKoroyama*

\begin{abstract}
Synthetic studies on the clerodane diterpenoids, a rapidly growing group of natural products, are reviewed from the standpoint of stereocontrols for the construction of a unique four contiguous stereogenic centers on their bicyclic skeleton. Strategies for the clearance of the stereochemical problems are described according to the types of major stereochemical features-namely trans and cis with respects to the ring fusion, and cis and trans disposition of $\mathrm{C}_{1}$-unit at $\mathrm{C}-8$ and $\mathrm{C}-9$ positions. The description involves the methods for enantioselective synthesis. Brief mentions are made on the synthetic methods for the related natural products (sesqui-, di- and sesterditerpenoids) with “clerodane" skeleton or substitution (hence with common problems of the stereocontrol) and on the investigations for the construction of the specific groupings in bioactive clerodane diterpenoids. The preliminary approaches as well as the methods used in the successful total synthesis are introduced in the modern light of stereocontrols.
\end{abstract}

Key words : Clerodane diterpenoid synthesis; Stereocontrol; Reductive alkylation; Cuprate conjugate addition; Stereocontrolled cyclization; Stereoselective Diels-Alder reaction; Enantioselective synthesis ; Bioactive diterpene.

\section{1.はじめに}

この半世紀に急激な発達を遂げた天然物合成におい て，立体選択性の問題は中心課題であった。この四半世 紀では鎖状立体制御，エナンチオ選択的合成の研究も活 発に行われ，立体選択的合成の方法論も大枠としてはほ ぼ確立したともいえる段階にきている。

クレロダンジテルペンは,この 20 年間ほど筆者のグ ループで合成研究を行ってきた一群の天然物で, 相連続 した 4 個の立体中心を含むのが構造的特徴である。最近 になってようやく合成研究も増えてきたので, この半世 紀に蓄積されてきた立体制御の方法がどのように応用さ

\section{* 大阪市立大学理学部物質科学科}

* Department of Material Science, Faculty of Science, Osaka City University

れ，またどのような新しい試みがなされているかの観点 から解説を試みる。

\section{2. 合成標的としてのクレロダンジテルペノイド}

\section{1. クレロダンジテルペノイドの構造の多様性}

クレロダンジテルペンは, 1 の構造を持つ二環性天然 物の総称である1)。最初の例は, 1956 年にBartonによっ て構造(立体構造は一部不明)の提出されたコロンボ根の 成分 columbin 2 であるが2), グループ名は後で構造決定

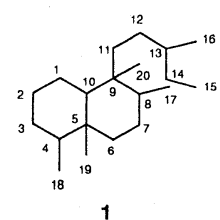

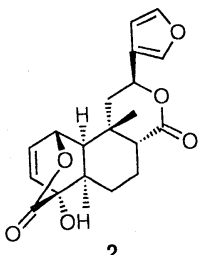

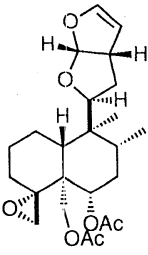

3 
された西洋くさぎの成分 clerodin 3 に由来する ${ }^{3)}$ 。その 後単離構造決定された化合物の数は急速に増加し, 現在 では 800 種を超える大グループとなっている。生合成的 には, geranylgeranyl pyrophosphate 4 の環化によって 生じた labdadienyl カチオン 5 が, さらにスキーム 1 に

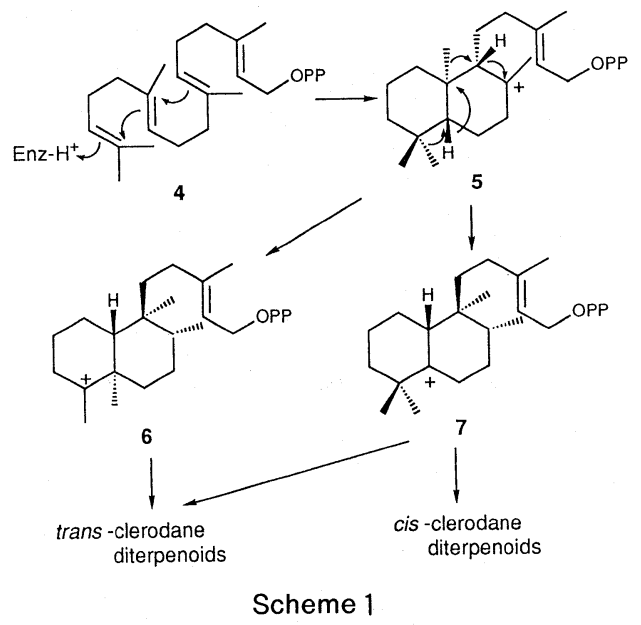

示すような背骨転位を起こして形成されると考えられて いる。この転位反応がC-4 位のメチル基の転位まで協 奏的に進めば，環結合はトランスとなるが，クレロダン ジテルペンの約 $1 / 4$ はシス環結合を持ち, 段階的な経路 も存在することになる。また C-17 およびC- 20 の $\mathrm{C}_{1}$ 工 ニットは,生合成機構と合致してほとんどシスであるが, 数は限られるがトランス配置を持つ化合物もある。C-4 は生合成的理由から, 多くの場合 $\mathrm{sp}^{2}$ 炭素原子で立体化 学上の問題とならない。絶対構造は, ent-labdadienyl 力 チオン 5 に由来する clerodin 3 の型のものが多いが, 逆 の絶対配位を持つ場合もある。クレロダンジテルペンの 絶対構造は, clerodinのそれがX 線の異常分散を利用し て決められた時の手違いで, 1979 年に訂正されるまで 逆の立体配位が与えられていたことで混乱した ${ }^{4.5)}$ 。そ こで訂正以後であることを示すために, clerodin 型を $n e 0$, 逆の絶対構造の場合を ent-neo という接頭語をつけ て区別する方法がとられている5 。骨格のほとんどすべ ての位置での酸素化体が知られており, また酸化の程度 もまちまちで多彩な化合物群を構成している。後で述べ るように特定の酸化形態が, 生理活性と結びついている 場合もある。

\section{2. クレロダンジテルペンの類縁化合物}

クレロダンジテルペンと生合成的に関連を持つ類似体 のグループがいくつか知られ，これらは当然合成のうえ
でも共通な面を持っている。C-19を欠くノルクレロダ ンジテルペン, 背骨転位が C-5 で止まったイソラブダ ンジテルペン, [5.4.0]-ウンデカン骨格あるいは[5.3.0] ーデカン骨格を持つなどのジテルペンで，それぞれの例 として, teucvidin $8^{6)}$, ambliol B $9^{7)}$, pilosanone A $10^{8}$, portulal 119)をあげておく。またジテルペン以外にも， 環の置換様式がクレロダンジテルペンと同じで，した がって合成面でも共通性を持つ化合物群もある。海藻あ るいは海綿の成分として見いだされているセスキテルペ ンキノンあるいはフェノール類には，トランスおよびシ スのクレロダン環を持つものが多数存在する(例えば avaron 12, arenarone $\left.13^{11)}\right)^{10}$ 。クレロダン環を持つセ スターテルペンもいくつか知られている(例えば palaunolide $\left.14^{12)}\right)^{10)}$ 。
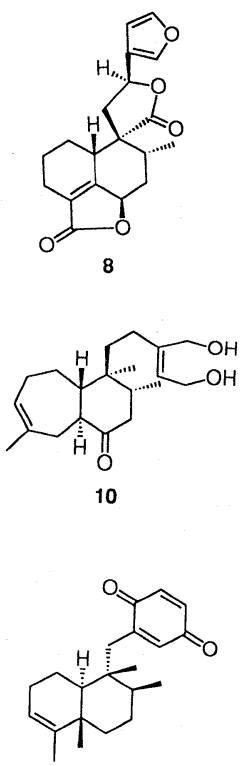

12
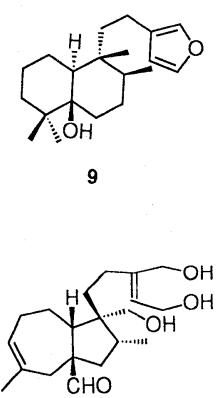

11

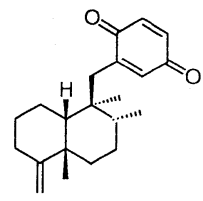

13<smiles>C=C1CCC[C@]2(C)[C@H]1CC[C@@H]1C/C(=C\C=C\C3=CC(=O)OC3)CC[C@@H]12</smiles>

\section{3. 生物活性 ${ }^{11}$}

クレロダンジテルペンの中で生物活性が知られている 化合物は必ずしも多くないが，むしろ調べられていない 場合が多いともいえる。もっともよく知られているのが, clerodin に代表される昆虫摂食阻害作用，あるいは関連 した殺虫作用である ${ }^{13)}$ 。すなわち，〈まつずら科(Clero- 
dendron, Caryopteris)あるいはしそ科(Ajuga, Teucrium) に含まれるクレロダンジテルペンは, 多種の植物害虫に 椇食阻害作用を示すことが報告されているが，それらの すべてが 6 位に酸素官能基を持つことが特徵である。し かしこのことが生物活性の条件ではないようで, kolavenol 1514) あるいは hardwickiic acid 16 ${ }^{15)}$ でもある 種の昆虫に対して摂食阻害あるいは殺虫作用を示すこと が報告されている。抗微生物性, 抗菌性, 抗ウイルス性 あるいは抗アメーバ性など, 種々の生物活性がいくつか の化合物について知られている。例にあげると不完全菌 の代謝物である clerocidin 17 は興味ある抗菌性を示 し ${ }^{16)}$, 放射菌より得られる terpentecin 18 は抗菌性と抗 腫瘍性を持っている ${ }^{17)}$ 。抗腫瘍性を持つ化合物としては,

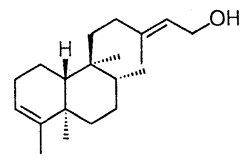

15

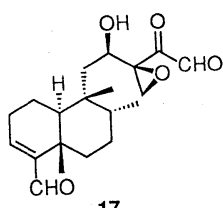

17

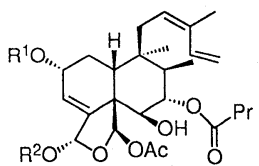

$19 R^{1}=M e ; R^{2}=A c$

$20 R^{1}=H ; R^{2}=C O P r$

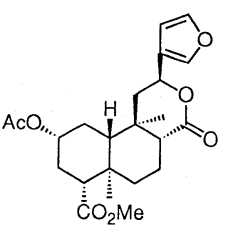

22

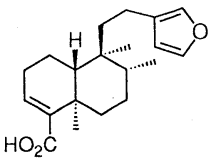

16

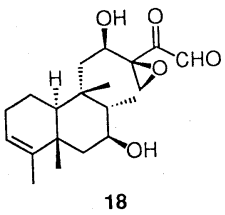

18

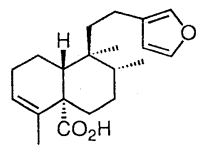

21

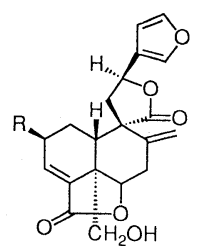

$23 \mathrm{R}=\mathrm{H}$ $24 \mathrm{R}=\mathrm{OH}$

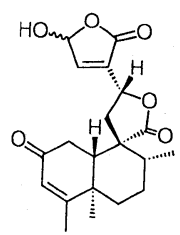

25

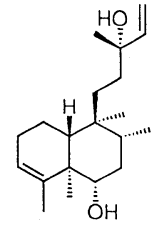

26
その他 teucvidin 8, Flacourtiaceae 科の植物の成分 19 および 20 などが報告されている ${ }^{1)}$ 。魚毒性を示す化合 物としては，南洋のくまつずら科の植物成分 maingayic acid $21^{18)}$ ，あるいはせいたかあわだちそうの成分である solidagolactone 類 ${ }^{19)}$ が知られている。 divinorin A 22 は, 幻覚性のメキシコ産の植物より単離され, 向精神作用を 持つとされている ${ }^{20)}$ 。その他抗消化性潰瘍作用を持つ pluanol B 23 およびC 24 ${ }^{21)}$ あるいは抗炎症作用を示す cajucarinolide $25^{22)}$, シダ植物生長抑制作用 ${ }^{23)}$ を持つク レロダンジテルペン 26 などが報告されている。

\section{3. 合成戦略と合成研究のあらまし}

クレロダンジテルペノイドの合成の中心課題は，環結 合を含む 4 個の連続した立体中心をいかに立体選択的に 構築するかである。この問題の解決には，この半世紀に 蓄積された環状化合物の反応の立体制御の知識が基礎に なる。しかも立体中心が密集しているために，合成デザ インに用いられる変換が限定される一方，ジアステレオ 場区別の可能性が十分考えられる状況にはある。これら のことを考慮に入れた種々の戦略が，骨格の立体選択的 構築のために展開されている ${ }^{24)}$ 。また望ましい方向の立 体制御を行うために，制御基を利用することなどもしば しば行われている。立体中心導入の順序については種々 の方法がとられているが，一度にできるだけ多くの立体 中心が確立されればより効率的である。また，エナンチ 才選択的合成あるいは環状の特定位置への酸素官能基の 導入など，目的に適合した戦略も必要となる。また，ク レロダンジテルペノイドには環結合がトランスおよびシ スの 2 群があるが，環結合の立体中心を最後に導入する と，両群の化合物を共通な中間体より合成できる可能性 があり，汎用的になる。

クレロダンジテルペノイドの全合成の完成例は，トラ ンス化合物が 7 , シスが 3 , 関連化合物で 5 例を数える。 ただし骨格合成の類型としては，トランスで 4 法，シス で 3 法となる。そのほか天然物の合成にいたっていない 試みも多く報告されており，以下にこれらを含めて紹介 する。

\section{4. トランスクレロダンジテルペンの合成}

\section{1. 還元的アルキル化を用いる方法}

$\Delta^{1,9}$-オク夕-3-オン誘導体のアルカリ金属還元 (Birch 還元)では， $\beta$-炭素の立体配位が熱力学的に安定な方向 に起こり，トランス体を与えることがよく知られてい $3^{25)}$ 。化合物 27 についての場合，さらに中間に生じた エノレート 28 をアルキル親電子剤でトラップすると(還 
元的アルキル化), 都合のよいことにアルキル基は 1,3 の位置にある核間置換基の立体障害により, $\beta$-側より 選択的に導入される。これらのことによって一度にトラ ンスクレロダン骨格の C- $5, \mathrm{C}-9, \mathrm{C}, \mathrm{C}-10$ の立体中心が構 築できる(スキーム 2$)$ 。クレロダンジテルペンの最初の 合成となった柿沢の annonene 38 の合成では(スキーム $3)^{26)}$ ，まず金属還元がトランスの環結合の形成に用いら れている。さらにC-9 の立体中心の構築には Claisen 転

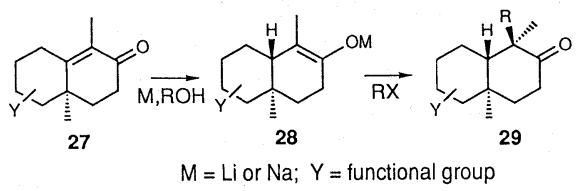

Scheme 2
位，C-8の構築には $\Delta^{8,17}$-オレフィン 34 の接触還元が用 いられているが，十分な立体選択性は達成されていない。 還元的アルキル化の利用を最初に試みたのは, Ardon, Jimenez, Halsall であるが27), その後 Sharma の avarol 155 の合成 $(9 \text { 参照 })^{28), * 1)}$, de Groot の epi-ajugarin-I 51 の合成 ${ }^{30)}$, Kende の ajugarin-IV 47 の合成 $\left(\right.$ スキーム 4) ${ }^{31)}$ に扔いて相次いで用いられた。Kende の合成では，残る C-8 の立体中心の導入に再びエノン 43 の金属還元が利 用されている。de Grootの合成では, この目的にエノン 49 の接触還元を行っているが(スキーム5), この場合 $\alpha$-面にかさ高いテトラヒドロフラン環があることで必 要な立体制御が達成されている。

*1）後に還元的アルキル化法を利用した, 柿澤らの中間体 34 の合成も 報告している29)。
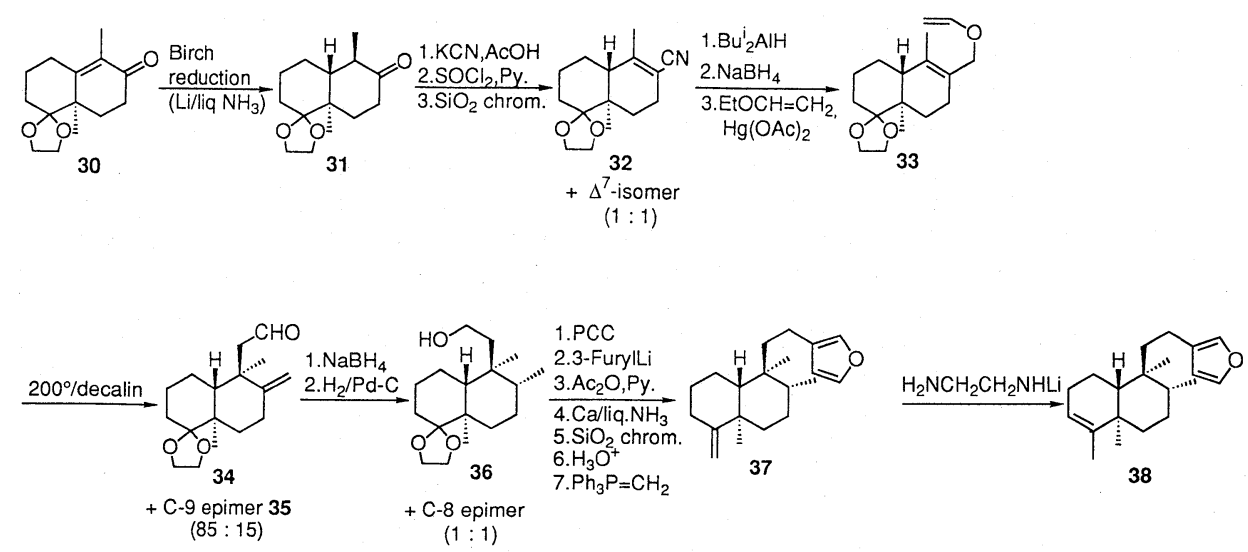

Scheme 3
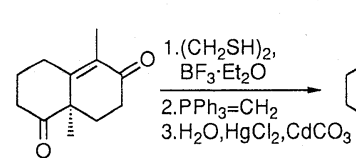

3. $\mathrm{H}_{2} \mathrm{O}, \mathrm{HgCl}_{2}, \mathrm{CdCO}_{3}$<smiles>C=C1CCCC2C1C=CC(=O)C21CC=CC1</smiles>

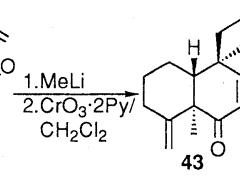

40<smiles>C=C1CCCC2=C(C)C(=O)CCC12</smiles>

1.Li/THF,liqNH 2. $\mathrm{LiAlH}_{4} / \mathrm{Et}_{2} \mathrm{O}$,
$\frac{-42^{\circ}, 20 \mathrm{~min}}{3 . \mathrm{SiO}_{2} \text { chrom. }}$

1. $\mathrm{KOH}(1.1 \mathrm{eq}) / \mathrm{MeOH}$ 1.KOH(1.109)<smiles>CO[C@H]1C[C@H](C)[C@H](OC)[C@@]2(CCCl)CCCC[C@H]12</smiles>
45
$\mathrm{CH}_{2} \mathrm{Cl}_{2}$

4. $(\mathrm{COCl})_{2} / \mathrm{CH}_{2} \mathrm{Cl}_{2}$

5. $\mathrm{Me}_{3} \mathrm{SiO},-\mathrm{OSiMe}_{3}$ 6. $\mathrm{H}_{3} \mathrm{O}^{+}$

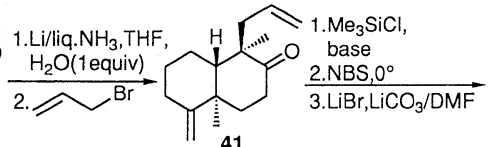

41 1. $\mathrm{ClCH}_{2} \mathrm{OMe}$ $\mathrm{Pr}_{2}^{\mathrm{j}} \mathrm{NEt} / \mathrm{CH}_{2} \mathrm{Cl}_{2}$ $\frac{2 . \mathrm{Sia}_{2} \mathrm{BH} / \mathrm{THF} / \mathrm{A} \text {; }}{\mathrm{H}_{2} \mathrm{O}_{2} / \mathrm{NaOH}}$ 3.PDC/DMF $\begin{array}{ll}{ }_{44} \mathrm{OH} & 4 . \mathrm{NaClO}_{2} / \mathrm{Bu}^{\circ} \mathrm{OH} \\ & \end{array}$ 6-epimer (20:1) $\quad 5 . \mathrm{CH}_{2} \mathrm{~N}_{2}$

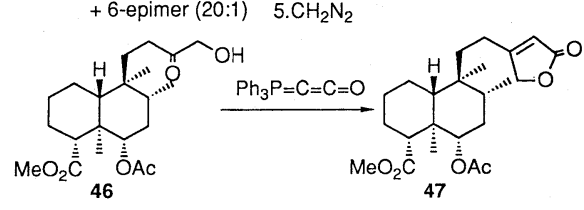

Scheme 4 


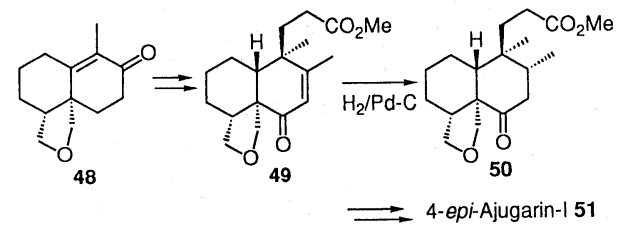

Scheme 5

\section{2. 共役付加を用いる方法}

環式共役エノンの立体選択的付加反応については多く

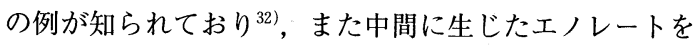
親電子剤でトラップすることで33)合成デザインを多様化 できる利点もある。Leyによる ajugarin-I 61 の合成( ス キーム 6)では，C-5 およびC-10の立体中心の導入に共 役付加反応が使われている。すなわち，まずシスージメ チル基を持つエノン中間体を Diels-Alder 反応を利用し てつくり， $\alpha$-面よりの立体選択的共役付加の条件を検 討した。しかし単に 52 に例えば $\mathrm{Me}_{2} \mathrm{CuLi}$ を作用させる と $\beta$-メチル化体のみが得られる。そこでモノエチレン チオケタール 53 とし, 2.2 当量の $\mathrm{Me}_{2} \mathrm{CuLi}$ を作用させ ると, 望ましい $\alpha$-面からのメチル化が起こることを見 いだした。これはエチレンチオケタール基にクプレート が強く配位することによりさらにかさ高くなり， $\beta$-位 からの試薬の攻撃が抑えられたものと考えられる。臭化 3-ブテニルマグネシウムの臭化銅存在化の反応も同様な 立体規制の下に進行し，アルキル化体54が収量よく得
られた。ただし合成をより convergentにするため酸素 官能基を含む反応剤を用いると, 収量は低下する。次に $55 \rightarrow 56$ の段階では C-4 位へのマスクされた $C_{1}$ ユニッ トの導入拉よびC-5 のトランス位へのヒドロキシメチ ル基の導入を tandem 共役付加-アルキル化反応を利用 して行っている。この際ビニル化の付加は, convex 側 である $\beta$ 面より起こり, 核間位へのホルムアルデヒド の反応は, 導入されたビニル基と反対の $\alpha$ 側より起こ る。

\subsection{Diels-Alder 反応を用いる方法}

分子間拉よび分子内 Diels-Alder 反応は，一度に多く の立体中心を立体選択的に構築できるので35), 多環性天 然物の合成に広く使用されている。Jung は36), 生物活性 を持つトランスクレロダンジテルペン plaunol B 23への アプローチとして，筆者らの第一世代合成法(後述)類似 のタイプの Diels-Alder 反応を検討し, 付加体 $64(\mathrm{R}=\mathrm{H})$ を収量よく得ている。しかし，まだ核間置換基の導入等 についての報告はでていない。そのほか分子間反応の応 用例として, Goldsmith の Ajugarin-I および-II の合成

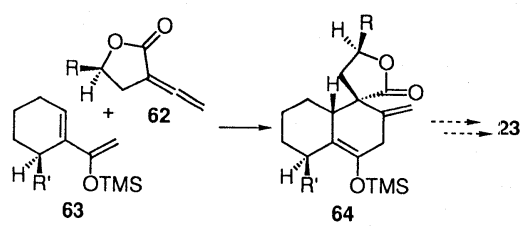

Scheme 7

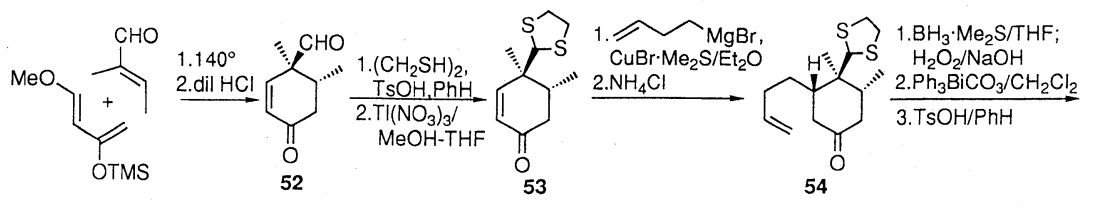

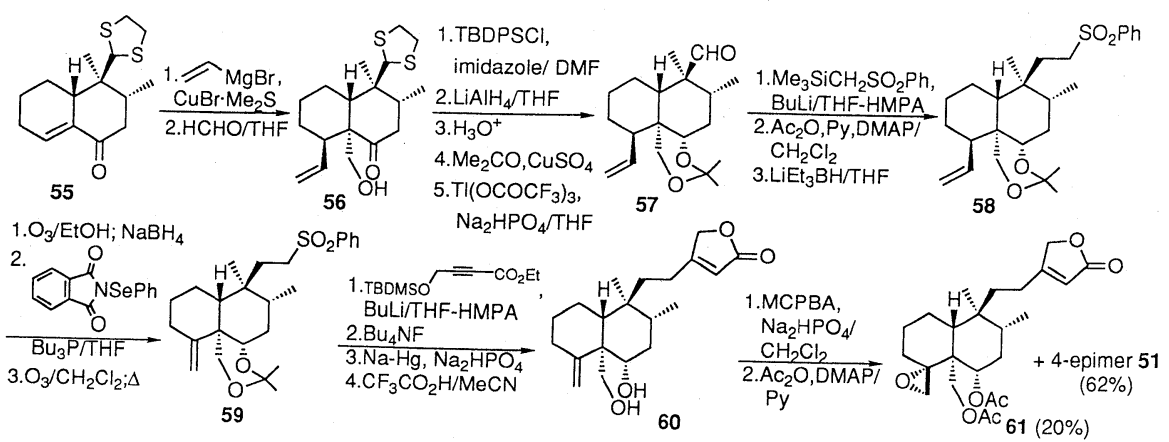

Scheme 6 
の試みがあるが37)，立体制御と直接関係していないので 省略する。次に分子内反応を用いた立体制御の試みを紹 介する。すなわち Taschner は, Bacchofertin 65 の合成 を目的として 66 のようなシクロへキサジエン誘導体の ルイス酸存在下での分子内 Diels-Alder 反応を検討し 67 の三環性中間体が好収量で得られることを見いだしてい る。そしてさらに共役付加による C-9 位置換基の導入 あるいは環開裂による C- $5, \mathrm{C}-8$ 置換基の整備等につい ても研究している ${ }^{38)}$ 。
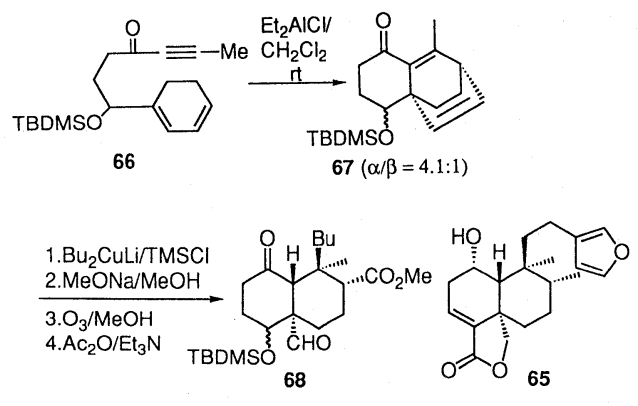

Scheme 8

\section{4. ケトン中間体の平衡化を利用する方法}

Piers は，2,5-ジメチルシクロヘキセ-5-エン-1-オン 69への共役付加抢よび分子内アルキル化によって得ら れたデカロン誘導体を平衡化させると，C-5，C-8, C-10 の立体中心において，トランスクレロダンジテル ペンの合成に望ましい立体化学を備えた化合物 70 が得 られることを見いだした。さらに( $p$-tolylsulfonyl)meth ylisocyanide(TOSMIC)によりシアノ誘導体に変換し, アルキル化すると置換基は $\mathrm{C}-5$ メチル基と逆の $\beta$ 側よ り導入され, 必要なすべての立体中心の構筑が完成する。 この中間体 72 より, セスターテルペン palaunolide 1439 および isolinaridiol diacetate $75^{40)}$ が全合成されている がここでは後者について経路をスキーム 9 に示す。

\section{5. その他の方法}

Lallemand は, clerodin 3 の合成を目的としたアプロー チを検討し，Leyによっても合成されているモデル体 79 を合成している(スキーム 10 $)^{41}$ 。ここの試みにおいて， 77 の末端ビニル基を開裂してアルデヒド基にすると自 然に環化し，トランスデカロン 78 が唯一の生成物とし て得られる。これは，反応の立体化学が熱力学的に規制 されたためと考えられる。さらに Lallemand は，C-9 $\mathrm{C}-11 \rightarrow \mathrm{C}-8$ の立体制御等についても検討している ${ }^{42)}$ 。

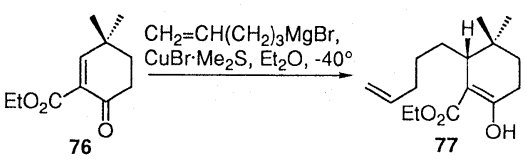

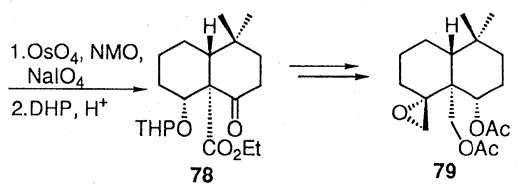

Scheme 10

\section{5. シスクレロダンジテルペンの合成}

\subsection{Diels-Alder 反応を用いる方法}

筆者らの第一世代合成法と呼んでいる方法は，1-ビ二 ルシクロヘキセンとクロロメチルマレイン酸無水物の間 の Diels-Alder 反応に基礎をおいたもので゙3)，もともと 関連ジテルペン portulal 1144) の合成に際して開発され たものである(スキーム 11)。すなわち立体選択的に好 収量で得られる付加体 80 は，C-8，C-9，C-10 におい てクレロダンジテルペンの合成の目的にかなった立体化 学を有している。残る核間位の立体中心の構築は，これ までのところエノレートアルキル化によってのみ達成さ れており，したがって現在のところこの方法の使途はシ

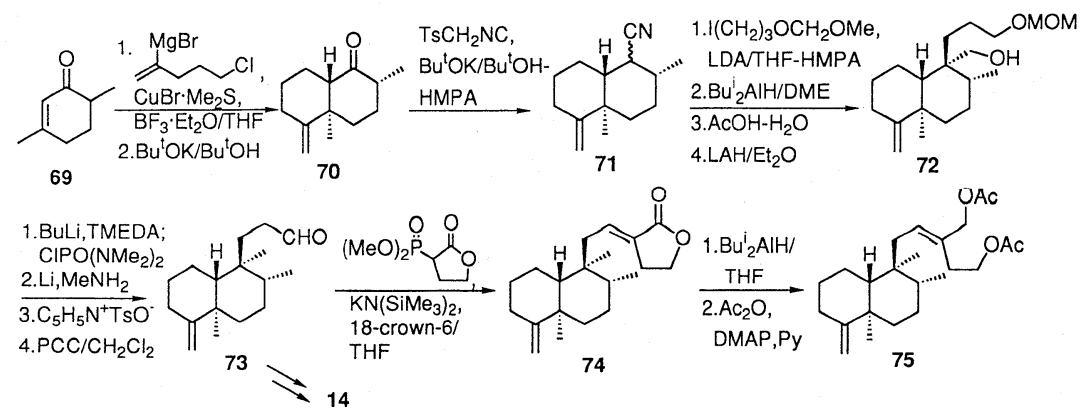

Scheme 9 


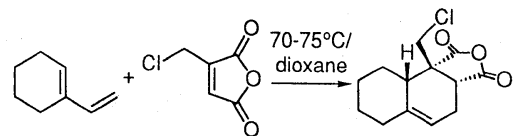

80
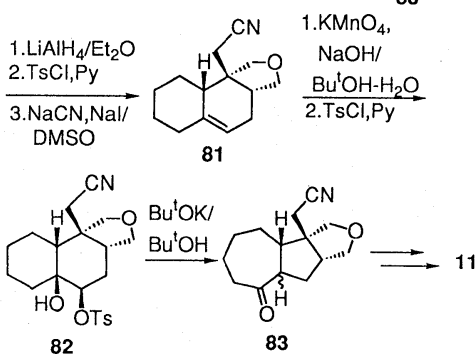

Scheme 11
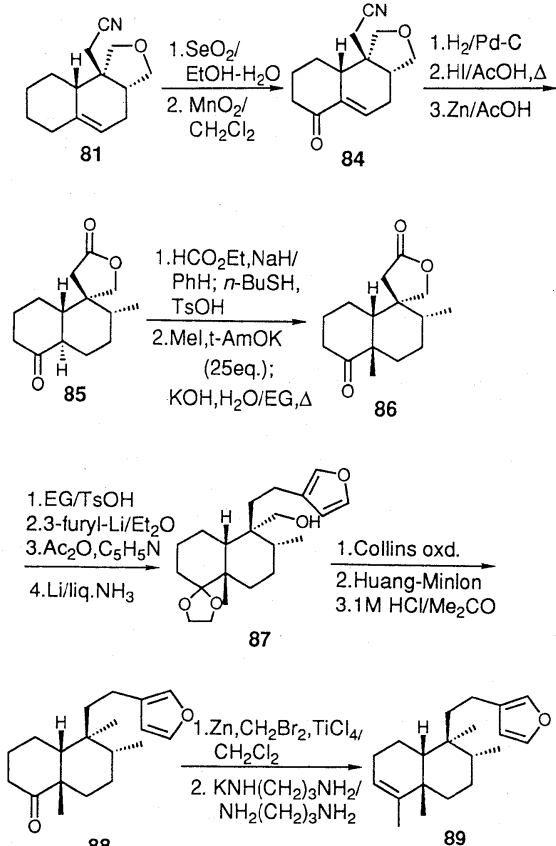

Scheme 12

ス体の合成に限られる。スキーム12にこの方法を用い た Solidago 属の植物から得られたシスクレロダンジテル ペン 89 の全合成の経路45)を示す。portulal 合成の中間体 81 より出発してデカロン体 85 に導き, Ireland の方法 でC-3 メチレンをブロックした後エノレートアルキル 化によるメチル基の導入を行った。立体障害のため難啮 したが，結局大過㮃の $t$-AmOK を用いることで目的を 達することができた。しかし，最大の難関は最終段階で あるケトン 88 に対する $\mathrm{C}_{1}$ ユニットの導入で, $\mathrm{MeMgBr}$ あるいは MeLi を反応させても立体障害のためかエノー
ル化が起こるだけで全然メチル化体が得られないことで あった。そこでこの合成は一時中断せざるを得なかった が，結局高井，野崎らのメチレン化反応剂(6)を用いるこ とで完成することができた。最近 Diels-Alder 反応のシ ス原理を，シスクレロダン骨格の核間位の立体中心の構 築に利用した試み ${ }^{47}$ が報告されている。すなわち 4,4 二置換 2,5-シクロヘキサジエンとブタジエンとの Diels -Alder 反応において, $\mathrm{n}=2$ の時 $91 / 92=5: 1$ の面選択 性が見られる(スキーム13)。
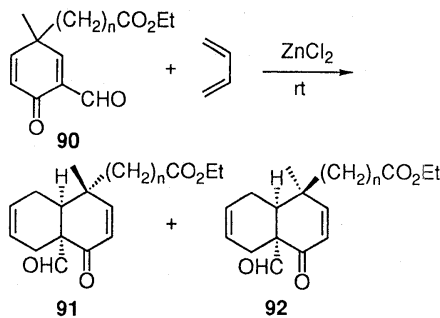

Scheme 13

\section{2. 閉環反応における立体制御を用いる方法}

筆者らは，次項で述べる第二世代合成法に続いて，新 しい型の立体制御を取り入れた第三世代合成法を開発し た。これは，スキーム14に示すように，分子内桜井反 応により二重の立体制御下に環形成を行いC-8，C-9, C-10 の立体中心を確立し，生成したエノレート中間体 94 を親電子反応剂でトラップすることにより C-5 の立 体中心を導入する方法である。環化は完全な立体制御下

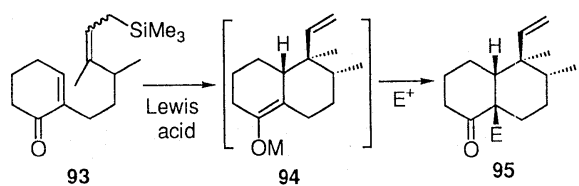

Scheme 14

に起こり ${ }^{48)}$ ，核間位への $C_{1}$ ユニットの導入もシスの方 向に立体選択的に起こる ${ }^{49)}$ 。まりワンポットの反応で， シスクレロダンジテルペンのすべての立体中心が立体選 択的に構築できるきわめて効率的な方法である。まずス キーム 15 に, 環化基質 93 の合成および環化反応を示す。 $94 \rightarrow 95$ のエノレートトラップは種々の検討を要したが 結局，基質抒よび $\mathrm{ClCH}_{2} \mathrm{SMe}(1.1 \mathrm{eq})$ のジクロロメタン 溶液をー $78^{\circ} \mathrm{C}$ で $\mathrm{TiCl}_{4}(2 \mathrm{eq})$ に滴下し， $0^{\circ}$ まで昇温する という条件で 100 を $80 \%$ の収率で得ることができた。 

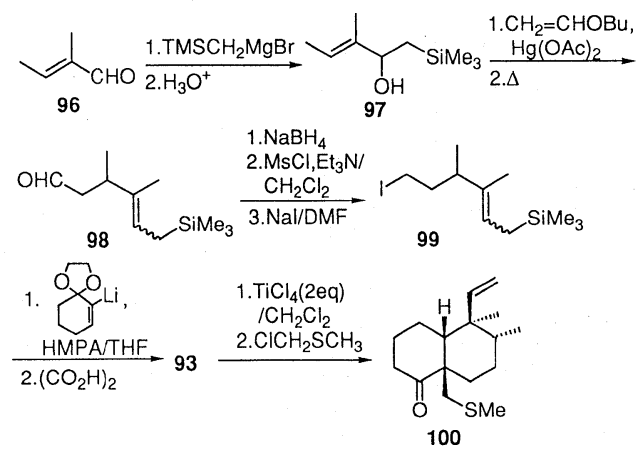

Scheme 15

ただしこの際 95(E=H)が, 20：1〜10：1の割合で副生 する。この反応における親電子活性種は $\mathrm{MeS}^{+}=\mathrm{CH}_{2}$. $\left[\mathrm{TiCl}_{5}\right]^{-}$と考えられ, 過剩の $\mathrm{MeSCH}_{2} \mathrm{Cl}$ の存在は 100 の 収量を低下させる。また環化の二重の立体制御は, C-10 と C-9 の相対配位に関する単純ジアステレオ選択, C-8 との相対配位に関するジアステレオ面選択に分かれ る。前者は，遷移状態におけるアリルシラン二重結合の エノン二重結合に対する配向が問題であり, 立体的およ び立体電子的に規制されたものと思われる (orientation control)。後者は二級メチル基の配座に関するジアステ レオ的遷移状態のエネルギー差によって決定されたもの と考えられる。これは一種の遠隔立体制御であり, 立体 選択合成の手段としての発展性を持っていると考えられ るので, folding strain stereocontrol という概念を用い た方法の一般化を試みている ${ }^{50)}$ 。第三世代合成法を用い て, ウンランの生物活性成分 linaridial 105 の全合成を 達成した $\left(\right.$ スキーム 16 ${ }^{49)}$ 。104の DIBAH 還元は, その ままでは試薬がアセタール部分に配位するためか収量が 悪いが, $\mathrm{Et}_{2} \mathrm{AlCl}$ を存在させ溶媒の比率を最適化するこ とで改善することができた。現在のところ第三世代合成 法は, シスクレロダンジテルペンの合成のみしか用いら れないが，トランス体の合成にも利用できる方法につい て検討中である。

\section{6. トランスおよびシスクレロダンジテルペンの 共通な中間体よりの合成}

共通の中間体より，トランスおよびシスの化合物を合 成できれば，合成法としてより一般的となりうる。この ような戦略から筆者らによって開発されたのが，第二世 代合成法である ${ }^{51)}$ 。108あるいは109のような中間体を デザインし，共役付加の反応剤あるいは条件を選択する ことでトランスあるいはシスのクレロダンジテルペンを 作り分けることを考えた。まず鍵中間体 108 と 109 の合 成は, Ziegler らによって報告されていたジビニル銅リ チウムの 3,4-ジメチル-2-シクロヘキセノン 106 への立 体選択的共役付加反応を利用して，スキーム17のよう に行った。このC-10の立体配位は, 環化反応の条件下 で熱力学的に規制され，望ましい立体配位を持つ化合物 が単一生成物として得られる。

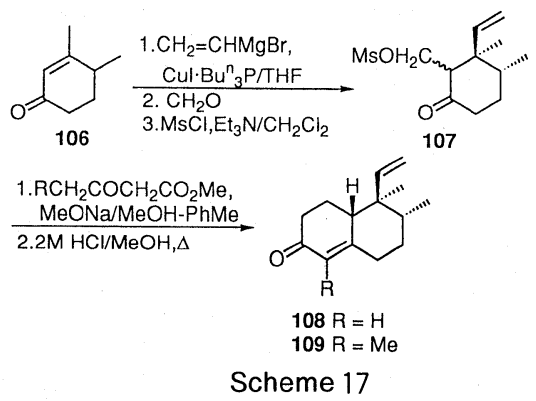

次にオクタロン 109 のトランスの核間位への $\mathrm{C}_{1}$ 工 ニットの導入の方法として, 永田のヒドロシアノ化法 ${ }^{52)}$ を検討した。熱力学的条件下 $\left(\mathrm{Et}_{2} \mathrm{AlCN} / \mathrm{PhH}\right)$ で, $\Delta^{1,9}-2-$ オクタロンで約 $5: 1$ の比でトランス体の生成が優先す ることが知られているが, 109 の場合 8 位のメチル基の 存在がシス体への遷移状態の不安定要因になるためか, ほとんどトランス体のみが得られた。このシアノ体は， C-18が官能化されたトランスクレロダンジテルペンの

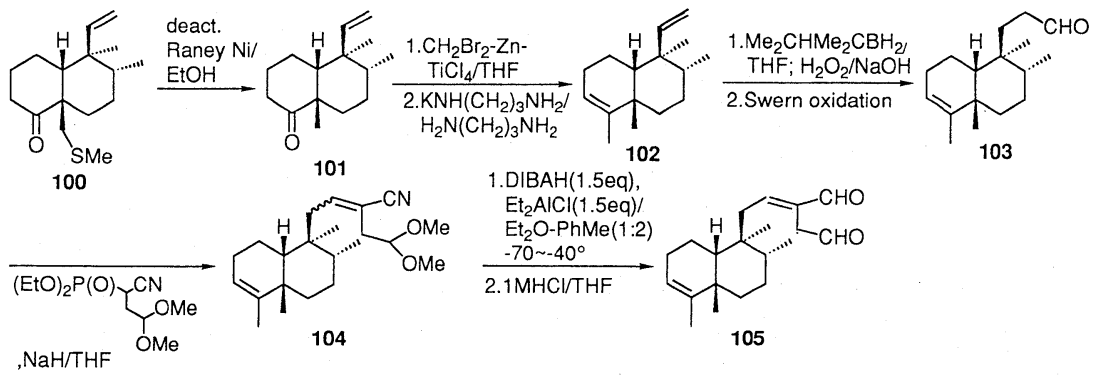

Scheme 16 

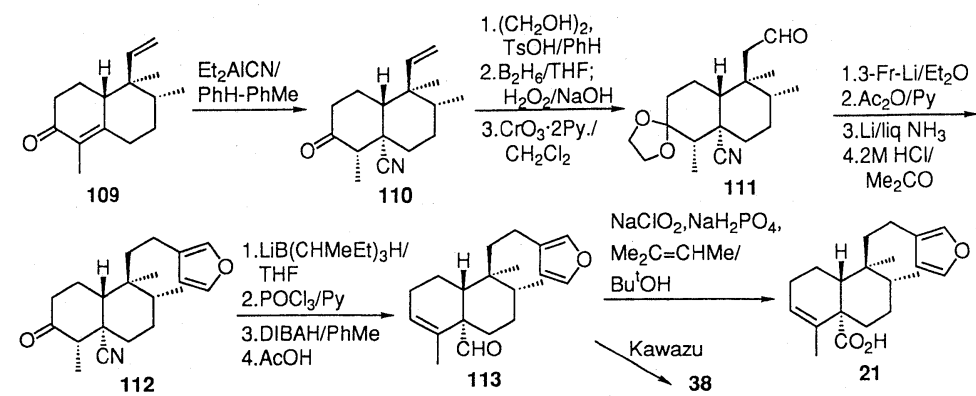

Scheme 18
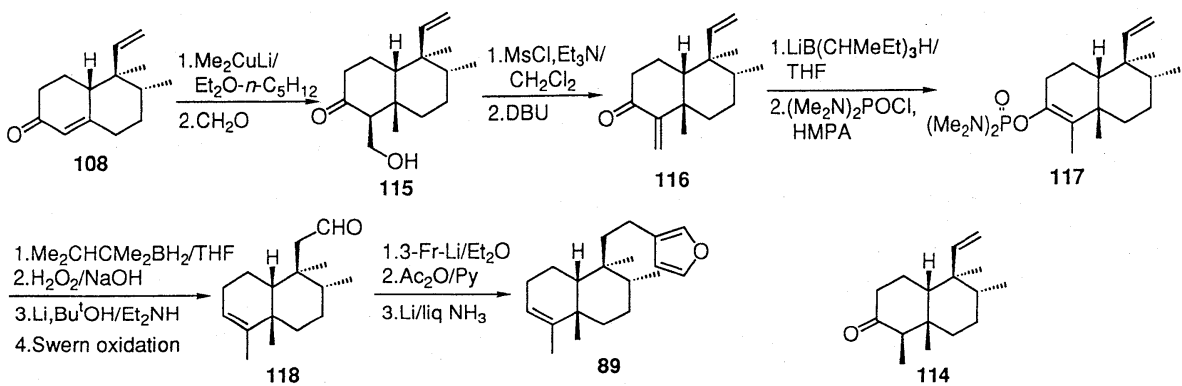

Scheme 19

合成に特に有用で, 魚毒性化合物 maingayic acid 21 を 標的として選びスキーム 18 に示した経路で全合成を達 成した。なおアルデヒド体 $113^{* 2}$ は，河津らにより annonene 38 に変換されているので ${ }^{18)}$ ，この合成は 38 の形 式的全合成も意味する。

オクタロン中間体 109 のシスの核間位への $C_{1}$ ユニッ トの導入には, アルキルクプレートの共役付加を考えた。 この際試薬の付加は, より立体障害の少ない convex 側 より起こると予想されるからである。実際に $\mathrm{Me}_{2} \mathrm{CuLi}$ の反応を行ってみると, 反応は確かに立体選択的でシス 体 114 のみが得られるが，低収率で $(<10 \%)$ かつ再現性 も悪い*3)。そこでより還元電位が高く反応性に富む才 クタロン中間体 108 に $\mathrm{Me}_{2} \mathrm{CuLi}$ を反応させ，得られた エノレート体をホルムアルデヒドでトラップする回り道 をして合成を進め，第一世代合成法で述べたシスクレロ ダンジテルペン 89 の全合成を行った(スキーム 19)。以 上のように，第二世代合成法に扔いて，共通の中間体か らトランス拉よびシスのクレロダンジテルペンを合成で きることが証明された。このことは，トランスおよびシ

*2）最近天然物としても見いだされている：K. Siems，X.A. Dominguez, J. Kupovic, Phytochemistry, 31, 4363 (1992)

*3）この合成の完了後，クプレートの共役付加反応を $\mathrm{Me}_{3} \mathrm{SiCl}$ の存在下 に行うと, 著しく加速されることが発表されたので53)試みたところ, 確かに 114 の収率は上がり $(18.5 \%)$ 再現性もよくなることが認められ たが, 条件の最適化等は行っていない。
スの異性体の合成が必要とされる場合に特に有効であ る。その例として, cascarilla 油の成分 cascarillone の構 造の訂正がある。すなわち cascarillone に対しては, 1976 年にシスクレロダンジテルペンの構造 119 が与え られていたが54)，この構造に相当する化合物 120 を中間 体 114 より合成したところ天然物と一致しなかった。次 に対応するトランス体 $121 を 110$ より合成したが，これ

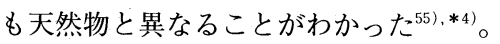<smiles>CC1(C)CCC23CCC(=O)CCC2C2CCc4cocc4CCC23C1</smiles>

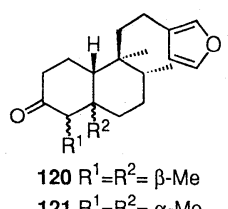<smiles>CC1CCC2c3cocc3CCC23CC(=O)CCC13</smiles>

122

そこで天然物を入手し $2 \mathrm{D}$ NMR 等で精査したところ， ケト基を 2 位に持つトランス構造であることが示唆され たので，中間体 110 より推定構造 122 を持つ化合物を合 成し, cascarillone の構造の問題に決着を与えることが できた ${ }^{56)}$ 。

*4）後になって，天然から対応する化合物が見いだされ，“transcascarillone”として発表されている。J.D. McChesney, E.R. Silveira, Fitoterapia, 61, 172 (1990) 


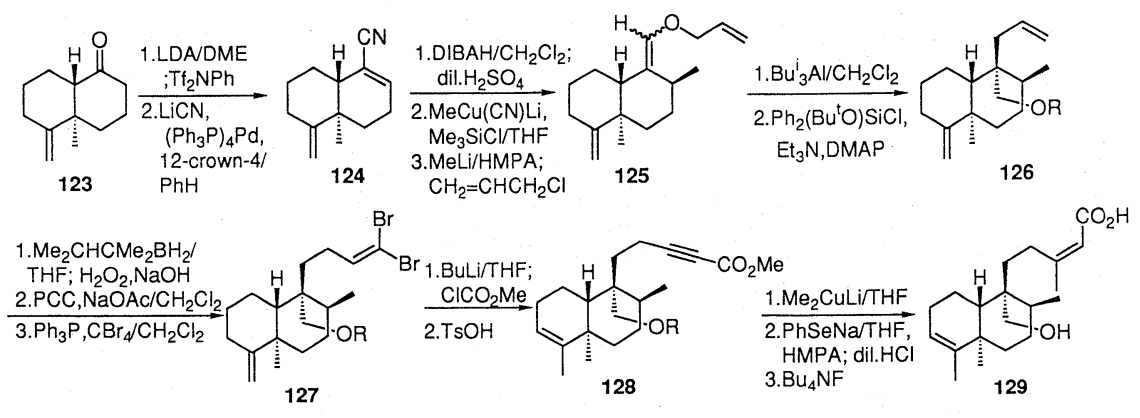

$\mathrm{R}=\mathrm{Si}\left(\mathrm{OBu}^{\mathrm{t}}\right) \mathrm{Ph}_{2}$

Scheme 20

\section{17,20-トランスクレロダンジテルペンの合成}

17,20-トランスクレロダンジテルペンの数は, クレロ ダンジテルペンの約 $3 \%$ 程度であるが，既に一部を紹介 したように, 興味ある生物活性を示す化合物も結構あり, 合成的にも魅力がある。現在のところ, 合成の完成例は, Piers によるStevia 属の成分, stephalic acid 129 につい

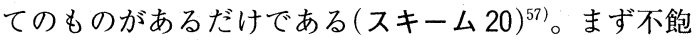
和ニトリル 124 より導いた不飽和アルデヒドに, メチル クプレートを共役付加させ，C-8 位に $\beta$-メチル基を立 体選択的に導入する。ついでアリルエノールエーテル体 125 を導き, 野崎らの条件下 ${ }^{53)}$ にClaisen 転位を行うと, より立体障害の少ない $\beta$ 側よりアリル基が導入され, C-9 の立体中心を望ましい形に構築することができた。 筆者の研究室でも, 最近第三世代合成法に基づいた 17,20-トランスクレロダン骨格構築のアプローチを検討 している ${ }^{59)}$

\section{8. エナンチオ選択合成}

最近では, 生物活性物質の合成はエナンチオ選択合成 が常識となってきている。クレロダンジテルペンの場合 は, まだ方法的に限られ, 実際に光学活性体の合成が達 成されているのは 2 例だけである。

最初の例は，筆者らの第二世代合成法に準拠した方法 である ${ }^{60)}$ 。この場合の問題は, 結局出発物質である 4ジメチル-2-シクロヘキセン 106 をキラルに得ることに 㷌せられる。2, 3 検討の結果, スキーム 21 に示すよう に，Enders の不斉アルキル化法を適用することによっ て，目的を達した。2-シクロヘキセノノンの $N$-amino2-methoxymethylpyrrolidine(AMP) ヒドラゾーン 130 の メチル化は既に Enders らによって報告されているが, 不斉收率は $61 〜 75 \%$ 程度である ${ }^{61)}$ 。この向上を種々検 討の結果，メチル化剤として TsOMe を用いることによ

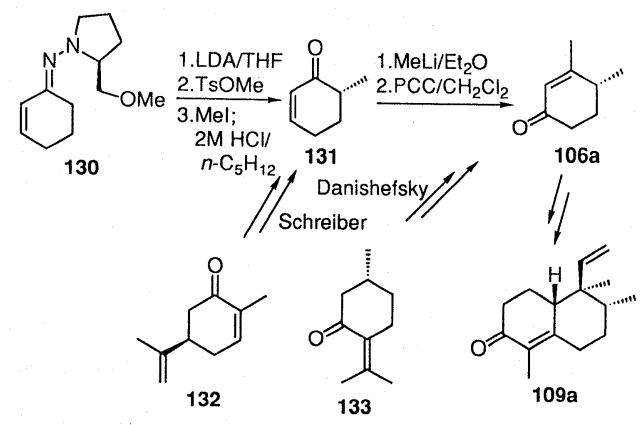

Scheme 21

り，事実上完全なエナンチオ選択性でメチル化体 131 を 得ることに成功した。このメチル化体に, MeLi と反応 させて得られた第三級アリルアルコールをクロム酸酸化 すると 3,5-ジメチル-2-シクロへキセノンが得られる。 SAMP ヒドラゾーンから出発して得た $106 \mathrm{a}$ は, 既に述 ベた環化を行うことにより, neo 型のクレロダンジテル ペンの合成の中間体 $(10 R)$-オクタロン誘導体 $109 \mathrm{a}$ に 導かれる。またRAMP ヒドラゾーンより出発すると, $e n t-n e o$ 型の化合物の合成に必要な $(10 S)$ 体が得られる はずである。さらに中間体の 131 は Schreiber により carvone 132 から ${ }^{62)}$, 106 a は Danishefskyによって pulegone 133 より ${ }^{63)}$ の誘導が報告されているので, これら両 対掌体が容易に入手しうるキラルプールからも，鍵中間 体 108 および 109 が合成できるわけで*5)，上記の不斉 合成法と合わせて第二世代合成法は, クレロダンジテル ペンのエナンチオ選択合成の上からもきわめて便利な方 法であると思う。上に得られた $(10 R)$-オクタロン誘導 体 $109 \mathrm{a}$ を用いて, 菊科, じゃけついばら科，うまのす

*5）ただし前者の方法は低収率の段階は含み，後者の方法は論文の sup plement によれば合成的スケールでの実験は行われていないなど，い ずれも実際の使用にあたってはさらに検討すべき問題を含んでいる。 


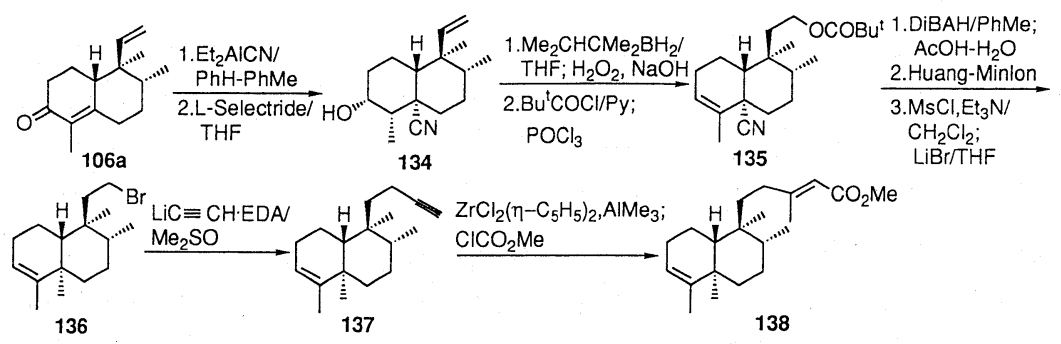

Scheme 22

ずくさ科などの植物成分として広く存在し，抗微生物活 性を示す(一)-kolavenic acid のメチルエステル 138 をス キーム 22 に示す方法で合成した。この合成は, クレロ ダンジテルペンの絶対構造を, 合成的に確認した最初の 例となった ${ }^{60)}$ 。またこの合成は，筆者らによって天然物 より得られる(一)-methyl kolavenate から鎮㽷作用など 興味ある生理活性を示す海産ジテルペン agelasine B 147 (後述) が誘導されているので64), この化合物の形式的 合成をも意味する。

次にPiers らは, (-)-pulegoneより得られる $(R)-5$ メチル-2-シクロヘキセノン 139 より, 既に述べた中間 体 142(70に異性化する前のシス体)のエナンチオ選択的 合成を行い ${ }^{65)}$ ，さらに天然物をも合成している ${ }^{66)}$ 。すな わち，まず不飽和ケトン139のキラリティを，トリメチ ルスズ試薬の共役付加・メチル化によって C-8 位(クレ ロダン骨格の番号)に移す。次にC-7 位のスタニル基を 制御基として環化を行い, 立体選択的に得られたデカロ ン誘導体 141 よりスタニル基を除去すると, 142 が得ら れる(スキーム23)。この光学活性中間体を用いて, kolavenol 15 の全合成，および基本的には筆者らと同じ 方法で(一)-agelasine B 147 の全合成を達成している。

Lallemand らは, $(S)$-prolinol をキラル補助基として 持つ1-ナフトエ酸誘導体の不斉 Birch 還元・アルキル 化反応を利用して, 筆者らの第二世代合成法の中間体と 類似のオクタロン中間体 152 の合成を報告している ${ }^{64)}$

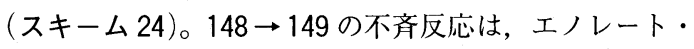
アルキル化の段階でキレーション制御をうけ, 高い光学

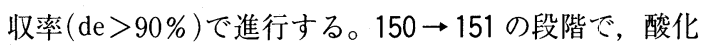

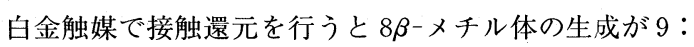
1 の比で優先するが, イリジュウム触媒で行うと $8 \alpha-$ 体 のみが得られることを見いだしている。

Smith IIIは， $(S)$-Wieland-Miescher ケトンより 2 段 階の反応で得られるオクタロン誘導体 153 の還元的アル キル化によりデカロン 154 を得ている(スキーム 25) ${ }^{65)}$ 。 Wieland-Miescher ケトンの不斉合成法は確立されてお $\eta^{66)}, 154$ はその対掌体を含めてトランス・クレロダン ジテルペンのエナンチオ選択的合成の有用な中間体にな りうるものと思われる。
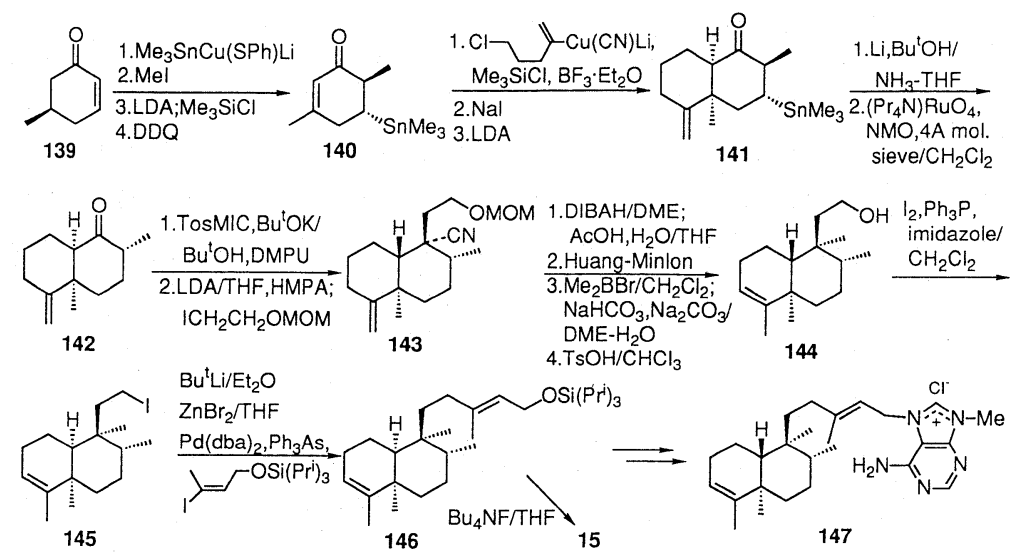

Scheme 23 


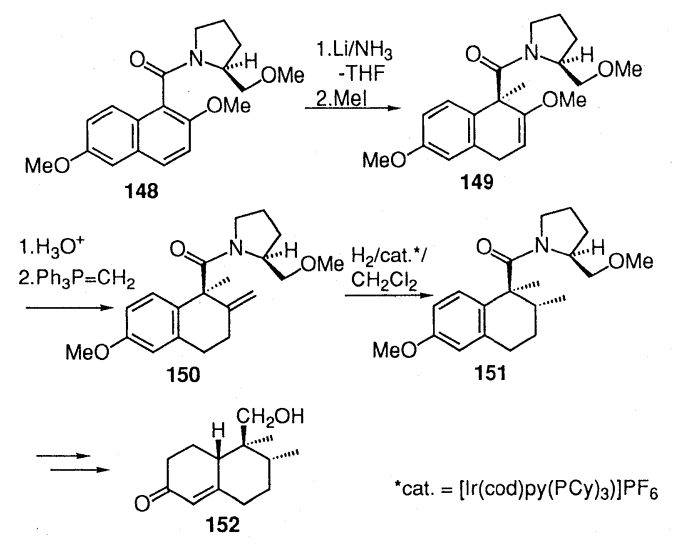

Scheme 24

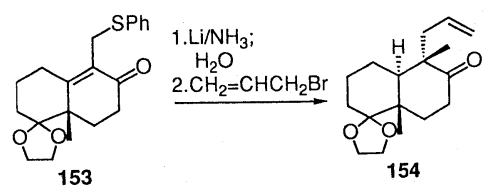

Scheme 25

\section{9. クレロダンジテルペンの類縁体の合成}

2. 2. で述べたように，類似骨格あるいは類似の置換 型を持つため，合成的にクレロダンジテルペンと共通点 を有する化合物が存在する。これら化合物の合成研究に ついて，簡単に触れておく。

Modified ドリマン骨格を持つ海産セスキテルペン類 では，Sharmaによる avarol 155 の合成例が唯一の完成 例である ${ }^{28)}$ 。またPiersによる海産抗微生物性セス夕ー テルペン palaulide 14 の合成については既に述べた (4.4.)。イソラブダンジテルペン類については, Harde, Bohlmann による $3 \alpha$-hydroxy- $5 \beta$, 10 $\beta$-epoxychiliolide 156 の合成 ${ }^{67}$ 抢よび Piersによる海綿の成分 ambliol B 9 の合成 ${ }^{68)}$ がある。そのほか類似ジテルペンの合成と して，筆者らの植物成長調節物質 portulal 11 の合成が ある(5.1.)。
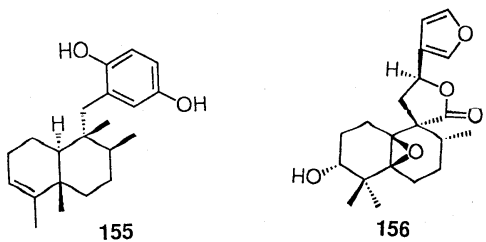

第 51 巻第 12 号 (1993)

\section{0. クレロダンジテルペンの官能基群の構築}

天然物合成のモデル反応としてあるいは構造-活性相 関の立場から, 特定のクレロダンジテルペンの官能基群 の合成法が研究されている。加藤による clerodin 類の perhydrofuro [2,3-b] furan 基を持つ類似体の合成, de Groot, Ley による clerodin および ajugarin 類のデカリ ン部分の類似体の合成等については, de Groot の総説を 参照されたい ${ }^{69)}$ 。Lallemand の clerodin 3 の合成を目標 とした一連の研究のうち一部は既に紹介したが, furofuran 側鎖部分の合成のアプローチについても最近発表 している ${ }^{70)}$ 。そのほか，菌の代謝産物で興味ある生物活 性を示す clerocidin 17 および terpentecin 18 の特異な官 能基群を持つ側鎖へのアプローチもなされている

\section{1. おわりに}

以上,この 30 年間に急激に増大した天然物の一グルー プであるクレロダンジテルペンの合成研究について紹介 した。デカリン骨格に環結合を含めた四個の相連続した 立体源中心が存在し，しかもそれらの配位が多様である ために，立体選択合成の標的として魅力ある対象であり， 類縁化合物を含めてクレロダンジテルペンの合成には多 彩な戦略が展開されている。そしてかなり広範囲の型の 化合物の合成が可能になってきているが，多種の構造を 持つ生物活性化合物の合成の要請に対応するためにはま だ不十分である。さらに新しい形の立体制御を戦略とし た挑戦が望まれる。

この小文がクレロダンジテルペンの合成研究に興味を もたれる方のご参考になれば，幸いである。

(平成 5 年 8 月 2 日受理)

\section{文献}

1) A.T. Meritt, S.V. Ley, Nat. Prod.Rep., 1992, 243

2) D.H.R. Barton, D.J. Elad, J. Chem. Soc., 1956, 2085 ; K.H. Overton, N.G. Weir, A. Wylie, ibid., C, 1966, 1482

3) D.H.R. Barton, H.T. Cheung, A.D. Cross, L.M. Jackman, M. Martin-Smith, ibid., 1961, 5061

4) N. Harada, H. Uda, J. Am. Chem. Soc., 100, 8022 (1978); G. Trivei, H. Komura, I. Kubo, K. Nakanishi, J. Chem. Soc., Chem. Commun., 1979, 885; I. Kubo, M. Kido, Y. Fukuyama, ibid., 1980, 897

5) D. Rogers, G.G. Uenal, D.J. Williams, S.V. Ley, G.A. Sim, B.S. Joshi, K.R. Ravindra- 
nanth, ibid., 1979, 97

6) Y. Nagao, N. Ito, T. Kohno, H. Kuroda, E. Fujita, Chem. Pharm. Bull., 30, 727 (1982)

7) R.P. Walker, D.J. Folker, J. Org. Chem., 46, 1098 (1981)

8) A. Osaki, K. Shibata, T. Tokoroyama, T. Kubota, J. Chem. Soc., Chem. Commun., 1987, 151

9) S. Yamazaki, S. Tamura, F. Marumo, Y. Saito, Tetrahedron Lett. , 1969, 359

10) D.J. Faukner, Nat. Prod. Rep., 9, 338 (1992) お よび同雑誌掲載の以前の総説

11) M.-L. Kondracki, M. Guyot, Tetrahedron, 45, 1995 (1989)

12) B. Sullivan, D.J. Faulkner, Tetrahedron Lett ., 23, 907 (1982)

13) T.A. van Beek, Ae de Groot, Rec. Trav. Chim. Pays-Bas, 105, 513 (1986)

14) J.J. Howard, J. Cazio Jr., D.F. Wiemer, J. Chem . Ecology, 14, 56 (1988)

15) B.M.R. Bandra, W.R. Wimalasiri, K.A.N.P. Bandra, Planta Med., 53, 575 (1987)

16) N.R. Andersen, P.R. Rusmussen, Tetrahedron Lett., 25, 465 (1984); N.R. Andersen, P.R. Rusmussen, C.P. Falshaw, T.J. King, ibid ., 25, 469 (1984)

17) T. Tamamura, T. Sawa, K. Isshiki, T. Masuda, Y. Homma, H. Iinuma, H. Naganawa, M. Hamada, T. Takeuchi, H. Umezawa, J. Antibiot., 38, 1664 (1985); K. Isshiki, T. Tamamura, Y. Takahashi, T. Sawa, H. Naganawa, T. Takeuchi, H. Umezawa, ibid., 36, 1819 (1985)

18) K. Kawazu, C. Nishino, R. McCrindle, D. McMaster, Agric. Biol. Chem., 36, 1245 (1972)

19) S. Manabe, C. Nishino, Tetrahedron, 42, 3461 (1986)

20) L.J. Valdes III, W.M. Butler, G.M. Hatfield, A.G. Paul, M. Koreeda, J. Org. Chem ., 49, 4716 (1984)

21) E. Kitazawa, A. Sato, S. Takahashi, H. Kuwano, A. Ogiso, Chem. Pharm. Bull., 28, 227 (1980)

22) Y. Ichihara, K. Takeya, Y. Hitotsuyanagi, H. Morita, S. Okuyama, M. Suganuma, H. Fujiki, M. Motidome, II. Itokawa, Plant Med ., 58, 549 (1992)

23) H.L. Siddiqui, K. Munesada, T. Suga, J. Chem . Soc., 1992, 781 ; K. Munesada, H.L. Siddiqui, T. Suga, Phytochemistry, 31, 1533 (1992)

24) E.J. Corey, X.-M. Cheng, "The Logic of Chemical Synthesis”, John Wiley and Sons, Inc., New York, 1989 , p. 47

25) H.O. House, "Modern Synthetic Reactions", second ed., Benjamin, Inc., Menlo Park, 1972, p.173; D. Caine, “Organic Reactions", Vol.23, ed. by W.G. Dauben, John Wiley \& Sons, Inc., New York,
1976, p.1 ; S.K. Pradham, Tetrahedron, 42, 6351 (1986)

26) S. Takahashi, T. Kusumi, H. Kakisawa, Chem. Lett. , 1979, 515

27) A. Ardon-Jimenez, T. Halsall, J. Chem. Soc., Perkin Trans. 1, 1978, 1461

28) A.S. Sharma, P. Chattopadhyay, J. Org. Chem., 47, $1727(1982)$

29) A.S. Sharma, A.K. Gayen, Tetrahedron, 41, 4581 (1985)

30) J.M. Luteijn, Ae de Groot, Tetrahedron Lett., 23, 3421 (1982)

31) A.S. Kende, B. Roth, ibid., 24, 3385 (1982)

32) P. Perlmutter, "Comjugate Addition Reaction in Organic Synthesis”, Pergamon Press, Oxford, 1992, p. 137

33) M.J. Chapdelaine, M. Hulce, "Organic Reactions", Vol.38, ed. by L.A. Paquette, John Wiley and Sons, Inc., New York, 1990, p.225

34) P.S. Jones, S.V. Ley, N.S. Simkins, A.J. Whittle, Tetrahedron, 42, 6519 (1986)

35) G. Desimoni, G. Tacconi, A. Barco, G.P. Pollini, "Natural Ptroducts Synthesis Through Pericyclic Reactions", American Chemical Society, Washington, 1983, p.119

36) M.E. Jung, C.N. Zimmermann, J. Am. Chem. Soc., 113, 7813 (1991)

37) D.J. Goldsmith, G. Srouji, C. Kwong, J. Org. Chem. , 43, 3182 (1978) ; R. Desphande, D.J. Goldsmith, 201st. ACS National Meeting, Atlanta, April, 1991, Abstracts of Papers, ORGN, No.188

38) M.J. Taschner, "Selectivities in Lewis Acid Promoted Reactions”, ed. by D. Schinzer, Kluwer Academic Publishers, Dordrecht, 1989, p.227 ; M.J. Taschner, P. T. Cyr, Tetrahedron Lett ., 31, 5297 (1990)

39) E. Piers, J.S.M. Wai, J. Chem. Soc., Chem. Commun., 1987, 1342

40) E. Piers, J.S.M. Wai, ibid., 1988, 1245

41) H. Bouchard, J.Y. Lallemand, Tetrahedron Lett., 31, 5151 (1990)

42) H. Bouchard, R.Y. Lallemand, ibid., 32, 5953 (1991)

43) K. Matsuo, T. Tokoroyama, T. Kubota, Chem. Lett., 1973, 397 ; T. Tokoroyama, K. Matsuo, T. Kubota, Tetrahedron, 34, 1907 (1978)

44) R. Kanazawa, H. Kotsuki, T. Tokoroyama, Tetrahedron Lett., 1975, 3651; T. Tokoroyama, K. Matsuo, H. Kotsuki, R. Kanazawa, Tetrahedron, 36, 3377 (1980)

45) T. Tokoroyama, R. Kanazawa, S. Yamamoto, T. Kamikawa, H. Suenaga, M. Miyabe, Bull. Chem. Soc.Jpm., 53, $1698(1980)$

46) K. Takai, Y. Hotta, K. Oshima, H. Nozaki, ibid ., 
53, 1698 (1980); L. Lambardo, Org. Synth., 65, 81 (1987) ; S.H. Pine, “Organic Reaction”, Vol.43, ed. by L. A. Paquette, John Wiley and Sons, Inc., New York, 1993, p.1

47) H.-J. Liu, Y. Han, Tetrahedron Lett., 25, 5067 (1987)

48) T. Tokoroyama, M. Tsukamoto, H. Iio, ibid ., 25, 5067 (1984)

49) T. Tokoroyama, M. Tsukamoto, T. Asada, H. Iio, ibid., 28, 6645 (1987)

50) T. Tokoroyama, K. Okada, H. Iio, J. Chem. Soc., Chem. Commun., 1989, 1572

51) T. Tokoroyama, K. Fujimori, T. Shimizu, Y. Yamagiwa, H. Iio, ibid., 1983, 1516; T. Tokoroyama, K. Fujimori, T. Shimizu, Y. Yamagiwa, M. Monden, H. Iio, Tetrahedron, 44, 6607 (1988)

52) W. Nagata, M. Yoshioka, "Organic Reactions", Vol.25, ed. by W.G. Dauben, John Wiley and Sons, Inc., New York, 1977, p.255

53) B.H. Lipschutz, S. Sengupta, “Organic Reactions”, Vol.41, ed. by L.A. Paquette, John Wiley and Sons, Inc., New York, 1992, p.205

54) A. Claude-Lafontaine, M. Rouillard, J. Cassan, M. Azzaro, Bull. Soc. Chim. Fr., 1976, 1516

55) H. Iio, K. Fujimori, Y. Yamagiwa, M. Monden, T. Tokoroyama, J. Chem. Soc ., Perkin Trans. 1, 1989, 1359

56) H. Iio, Y. Matsumoto, K. Shimokata, K. Shibata, T. Tokoroyama, ibid., 1989, 1360

57) E. Piers, F.F. Fleming, J. Chem. Soc., Chem. Commun., 1989, 1665

58) K. Takai, I. Mori, K. Oshima, H. Nozaki, Bull. Chem. Soc.Jpn., 57, 446 (1984)
59）野老山喬，加藤 仁，服部多恵子，飯尾英夫，第 36 回テルペンおよび精油化学に関する討論会予稿 集, 西宮, 1992, p.79

60) H. Iio, M. Monden, K. Okada, T. Tokoroyama, J. Chem. Soc., Chem. Commun., 1987, 358

61) D. Enders, H. Eichenauer. Chem. Ber., 112, 2933 (1978)

62) S.L. Schreiber, J. Am. Chem. Soc., 102, 6163 (1980)

63) S. Danishefskey, P. Harrison, M. Silvestri, B. Segmuller, J. Org. Chem., 49, 1319 (1984)

64) H. Iio, K. Asao, T. Tokoroyama, J. Chem. Soc., Chem. Commun., 1985, 774

65) E. Piers, J.Y. Roberge, Tetrahedron Lett . , 32, 5219 (1991)

66) idem, ibid., 33, 6923 (1992)

67) J. Lejeune, J.Y. Lallemand, ibid ., 32, 2621 (1991)

68) A. B. Smith III, R. MewShaw, J. Org. Chem ., 49, 3685 (1984)

69) H. Hagiwara, H. Uda, ibid., 53, 2308 (1988)

70) C. Harde, F. Bohlmann, Tetrahedron, 44, 81 (1988)

71) E. Piers, P.C. Marais, J. Chem. Soc., Chem. Commun., 1989, 1222

72) A. de Groot, T.A. van Beek, Rec. Trav. Chim. Pays-Bas, 106, 1 (1987)

73) H. Bouchard, J. Soulie, J.Y. Lallemand, Tetrahedron Lett., 31, 4509 (1981)

74) M. Bailey, I.E. Marko, W.D. Ollis, P.R. Rusmussen, ibid., 31, 4509 (1990)

75) M. Bailey, I. Staton, P.R. Ashton, I.E. Marko, W.D. Ollis, Tetrahedron: Asymmetry, 2, 495 (1991) 